\title{
PHARMACOLOGICAL EFFICACY OF TRICHODESMA INDICUM (LINN) R. BR., IN FOLK MEDICINE - AN UPDATED REVIEW
}

\author{
ALARMAL MANGAI S* \\ Department of Chemistry, Karpagam College of Engineering, Coimbatore, Tamil Nadu, India. Email: mangai24phyto@ gmail.com \\ Received: 23 December 2017, Revised and Accepted: 22 January 2018
}

ABSTRACT

The medicinal knowledge of herbal plants plays a predominant role in finding new sources of drugs in pharmaceutics. The plant Trichodesma indicum (Linn) R. Br. is a significant constituent of Boraginaceae family with prominent records in conventional folk medicine. The diverse uses of the entire plant parts are being widely studied by in vitro and in vivo experimental methods. The present work is aspired to provide a biological evaluation of the plant that has been explored so far on various parts of the plant such as roots, leaves, and seeds. It also aims to provide a scientific support to the medicinal properties of the various phytoconstituents that are isolated from the plant. Hence, the present review is a comprehensive literature analysis of chemistry, ethanol-pharmacology and the therapeutic uses of T. indicum.

Keywords: Boraginaceae, Ethanol-pharmacology, Folk medicine, Phytoconstituents, Trichodesma indicum.

(c) 2018 The Authors. Published by Innovare Academic Sciences Pvt Ltd. This is an open access article under the CC BY license (http://creativecommons. org/licenses/by/4. 0/) DOI: http://dx.doi.org/10.22159/ajpcr.2018.v11i3.24412

\section{INTRODUCTION}

T. indicum (Linn) R.Br. is generally known as Indian Borage and belongs to Boraginaceae family which is a major group of angiosperms. In Tamil, it is known as Adhapushpi that is flowers are bent downward. The plant is found as a weed throughout the greater parts of India and stony dry wastelands of Pakistan. In Pakistan, it has been found at low altitude in Karachi, Sindh, Balochistan, Chitral, Swat, Hazara, Jhelum, Dhamial, the Rawalpindi hills, Poonch, and Kashmir [1]. Later it has been distributed in many south Asian regions such as Bhutan and Burma [2].

\section{Description of the plant}

It is a hispid, erect or diffuse annual herb with single pale blue flowers with hairs springing from tubercles. The leaves are stalkless, opposite, lanceolate, $2-8 \mathrm{~cm}$ long pointed at the tip and heart-shaped at the base. The flowers occur singly in the axils of the leaves. The sepal tube (calyx) is a green hairy and $1-13 \mathrm{~cm}$ long with pointed tubes. The fruit is ellipsoid and is enclosed by the calyx. The plant is acrid, bitter in taste. The aerial part of the plant was shown in Fig.1.

In herbal medicinal Jargon, it is thermogenic, emollient, alexeteric, anodyne, carminative, depurative, febrifuge, and pectoral.

\section{LANDMARKS OF T. INDICUM IN FOLK MEDICINE}

The plant $T$. indicum has a good medicinal record in folk medicine curing various diseases. Its traditional uses are extensively summarized in Table 1 [3-13].

\section{PHYTOCONSTITUENTS}

A variety of bioactive constituents were reported to be present in the plant T. indicum [14-16]. The main phytoconstituents that are isolated from the plant arehexacosane, $\alpha$-amyrin, lupeol [17], nonsteroidal compounds [18], and fatty constituents [19]. n-Decyl laurate, n-tetradecanyl laurate, n-nonacosanyl palmitate, stigmast-5-en-3ß-ol21(24)-olide, n-pentacos-9-one, n-dotriacont-9-one-13-ene, Stigmast-

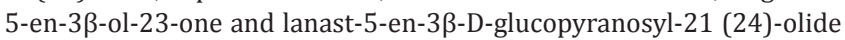
were isolated from ethanol extract of T. indicum [20]. The fatty acidsoleic, linoleic, palmitic, stearic, and linolenic acid were also identified and isolated from the seed oil [21]. The data are tabulated in Table 2. The presence of alkaloids in the plant was also confirmed in our previous study [22].

\section{PHARMACOLOGICAL STUDIES}

\section{Antidiarrheal potential}

The decoction obtained from the roots of T. indicum is generally ingested for curing diarrhea, dysentery, and fever which is an Indian habitual medicinal treatment. To evaluate the traditional claims, a study was undertaken by Behera et al.,[3] with several animal models. The ethanol extract of the roots was utilized in the study and found the inhibition of the castor oilinduced diarrhea and decreased propulsion of charcoal meal through the gastrointestinal tract. The castor-oil induced small intestinal fluid accumulation was also reduced. The results obtained substantiate this herbal remedy of the plant as a specific treatment for diarrhea in folk medicine [3].

\section{Anti-inflammatory activity}

The anti-inflammatory activity of $T$. indicum was assessed against edema produced by carrageenan, dextran, histamine, and serotonin and against the formation of granulation tissues by cotton pellets in rats. The effect was compared with the activity of indomethacin, cyproheptadine, and dexamethasone against different types of inflammation.

The chloroform extract at doses of 50, 100, and $200 \mathrm{mg} / \mathrm{kg}$ exhibited significant anti-inflammatory activity in acute and chronic inflammatory models $(\mathrm{p}<0.001)$. At $200 \mathrm{mg} / \mathrm{kg}$, the extract showed maximum inhibition of $48.12 \%$ in carrageenan-induced rat paw edema while the standard indomethacin inhibited it by $54.32 \%$ after $3 \mathrm{~h}$ of carrageenan injection. The extract of the specific concentrations $(50$, 100 , and $200 \mathrm{mg} / \mathrm{kg}$ ) significantly and dose-dependently inhibited Destran, histamine, and serotonin-induced rat paw edema compared with control group (vehicle treated). In the chronic inflammatory model, the extract inhibited the granuloma weight by $15.42 \%$ and $21.2 \%$, respectively, whereas the indomethacin and dexamethasone inhibited by $29.29 \%$ and $34.13 \%$, respectively. The experimental results confirmed the anti-inflammatory activity of the extract at the tested dose levels [22].

Antitussive potential on $\mathrm{SO}_{2}$-induced cough reflex in mice A study was carried out by Srikanth et al., to investigate the whole plant of T. indicum R.Br on sulfur dioxide-induced cough reflex using Swiss albino mice. The methanol extract of the plant has demonstrated significant inhibition $(\mathrm{p}<0.001)$ in the frequency of a cough in all the tested doses when compared with untreated control group. The effect persisted up to $90 \mathrm{~min}$ of its oral administration and is comparable 
Table 1: Usage of $T$. indicum plant parts in folk medicine

\begin{tabular}{|c|c|c|c|c|}
\hline S.No & Plant part used & Uses in folk medicine & Place of use & References \\
\hline \multirow[t]{2}{*}{1} & Roots & To reduce swelling & Chota Nagpur, India & {$[1]$} \\
\hline & & To cure body ache and anasarca & Kandhamal district, Orissa & [3] \\
\hline 2. & Leaves & $\begin{array}{l}\text { Healing of cuts, wounds, and } \\
\text { bleeding }\end{array}$ & $\begin{array}{l}\text { Kandhamal district, Orissa, and various places in } \\
\text { Tamil Nadu, India }\end{array}$ & [3-5] \\
\hline 3. & Fresh leaves & $\begin{array}{l}\text { To cure stomach upset and } \\
\text { dysentery to children }\end{array}$ & Tiruchirappalli, Tamil Nadu, India & {$[5-7]$} \\
\hline 4. & Leaves and roots & $\begin{array}{l}\text { To cure tumor, snake bite, and } \\
\text { Urinary diseases }\end{array}$ & Chhattisgarh, India & {$[8-10]$} \\
\hline 5. & Whole plant & Pain healing in joints & Marginal district, Orissa, India & {$[12]$} \\
\hline 6. & & $\begin{array}{l}\text { For indigestion and to kill } \\
\text { intestinal worms in cattle }\end{array}$ & $\begin{array}{l}\text { Abbottabad district, North-West Frontier province, } \\
\text { Pakistan }\end{array}$ & [11] \\
\hline 7. & & To cure Influenza and cough & Nara desert, Pakistan & [13] \\
\hline
\end{tabular}

T. indicum: Trichodesma indicum

Table 2: Phytoconstituents isolated from T. indicum

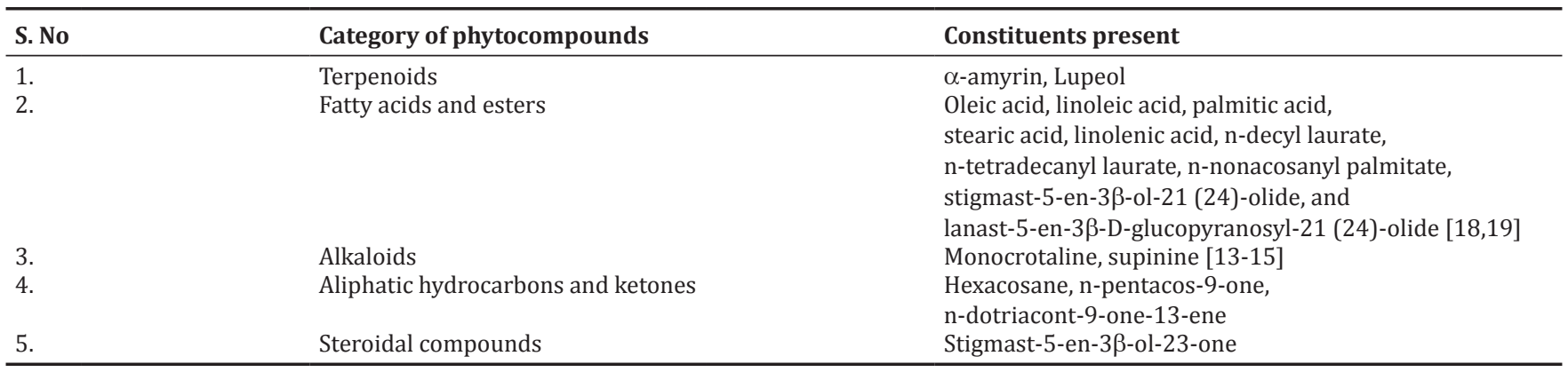

T. indicum: Trichodesma indicum

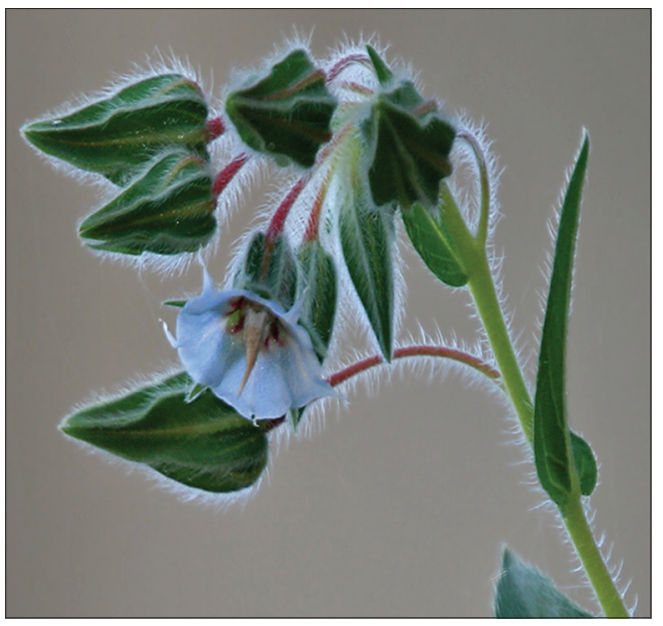

Fig. 1: Trichodesma indicum Linn. R. Br. plant

to that of the standard drug (codeine phosphate). In conclusion, the results of the study provided pharmacological evidence in support of folklore claim as antitussive agent [23].

\section{Antispasmodic and lipoxygenase inhibitory effect}

According to the study conducted by Taous Khan et al., in the evolution of the possible antispasmodic and lipoxygenase inhibitory activity of medicinal plants [24], T. indicum Linn. R.Br extract was tested on the isolated rabbit jejunum. The extract made a reduction in spontaneous and acetyl-induced contractions. It inhibited the intestinal contractions by $78 \%$ at $5 \mathrm{mg} / \mathrm{ml}$. The extract showed a good to excellent lipoxygenase inhibitory activity (64.5\%) on the tested enzyme [24].

\section{ENZYME INHIBITION ACTIVITY}

The ethanol extract of the plant was screened for enzyme inhibition activities against Urease and $\alpha$-chymotrypsin enzymes. Urease activity was determined by measuring ammonia production using the indophenols method [25]. The $\alpha$-chymotrypsin inhibitory activity was performed by the method described by Cannel et al. [26] and found that the extract has significant inhibition activity [27]

\section{ANTIMICROBIAL EFFECT}

Bovine mastitis is one of the most prevalent diseases in dairy cattle among the dairy farms in Tamil Nadu. Therefore, an analysis on antibacterial activity of plant was carried out in vitro mode by the agar disc diffusion method. Aqueous and methanol extracts were used at two different concentrations (100 and $200 \mathrm{mg} / \mathrm{ml}$ ). It was found to have the moderate antimicrobial activity, and the extracts did not show any activity against Klebsiella pneumoniae [28]. Further in vitro antimicrobial potential of ethanol extract of the plant root was also carried out along with its isolated compounds n-decyl laurate, n-tetradecanyl laurate,

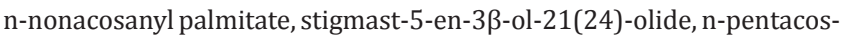
9-one, n-dotriacont-9-one-13-ene, stigmast-5-en-3 $\beta$-ol-23-one and lanast-5-en-3 $\beta$-D-glucopyranosyl-21 (24)-olide [20]. The extract exhibited potent growth inhibitory activity against Staphylococous aureus, Bacillus Subtilis, and Candida albicans with an minimum inhibitory concentration (MIC) value of $19.2 \mu \mathrm{g} / \mathrm{ml}$. Among all the isolated compounds, lanast-5-en-3 $\beta$-D-glucopyranosyl-21(24)-olide displayed strongest antibacterial activity against $S$. aureus with MIC value of $2.4 \mu \mathrm{g} / \mathrm{ml}$. The results obtained provide ground basis for the potential use of the ethanol extract of $T$. indicum root as well as the some of the isolated compounds in the treatment of infections associated with the studied microorganisms [20].

The effective resistivity against microorganisms of the plant was also identified by Saboo et al., against B. subtilis, S. aureus, Balantidium coli, Pseudomonas aeruginosa, Proteus vulgaris, C. albicans, Aspergillus flavus, and Aspergillus niger by disc diffusion method [29].

\section{PHYTOTOXIC AND INSECTICIDAL ACTIVITY}

To find some new natural sources of pesticides from botanical origin, crude extract of T. indicum R.Br, collected from Pakistan was investigated 
on the exploration of phytomedicinal and agrochemical potentials. The insecticidal activity was tested against B.Pisorum, Tribolium castaneum, and Rhyzopertha dominica. The extract showed excellent insecticidal activity against $R$. dominica and caused $80 \%$ and $40 \%$ mortality of these species, respectively. It is, hence, concluded that $T$. indicum shows a considerable insecticidal activity, especially against $R$. dominca and $B$. pisorum. Therefore, it could serve as a new source of bioinsecticide for products when stored for a prolonged period and also as an effective pest control in the agricultural field.

Further, in the analysis of ethanol extract of the plant against Lemna minor, the plant showed a good inhibitory activity of growth of L. minor by $60 \%$ at higher concentration $(500 \mu \mathrm{g} / \mathrm{ml})$. At low concentration of $50 \mu \mathrm{g} / \mathrm{ml}$, a weak inhibitory activity was observed (20\%). Therefore, it has been concluded that ethanol extract showed a tremendous phytotoxic activity against $L$. minor. Thus, the study recommended that the plant can be utilized as a natural herbicide and could be a rich source of bioactive agrochemical [30].

\section{ANALGESIC AND ANTIPYRETIC POTENTIAL}

The possible analgesic and antipyretic potential of the plant were studied using several experimental models. The analgesic activity was determined in chemicals (acetic acid and formalin) as well as thermal (tail immersion) pain models in mice using classical standard drugs. The ethanol extract at doses of 100, 200, and $400 \mathrm{mg} / \mathrm{kg}$ exhibited a significant $(\mathrm{p}<0.001)$ inhibition of acetic acid-induced abdominal constrictions in mouse. In the tail immersion models, the extract $(400 \mathrm{mg} / \mathrm{kg})$ showed a significant increase $(\mathrm{p}<0.001)$ in pain threshold to the meal stimulus and also in both the phase (early and late phase) of the hyper analgesic mode of formalin test. It also produced a dose-related fall in rectal temperature in rat for up to $3 \mathrm{~h}$ after its administration. The experimental results suggest that the analgesic effect of the extract may be due to inhibition of the synthesis and/or liberation of inflammatory mediators. The extract also had a significant effect in tail immersion test. Centrally acting analgesic drugs elevate pain threshold of animals toward heat. The effect of the extract on this pain models indicates that it may be centrally acting.

Drugs that are acting primarily on the central system will inhibit both phases (early and late phases) equally while peripherally acting drugs inhibit the late phase. The ethanol extract of the plant T. indicum inhibited both the phases of formation induced pain with a more potent effect on the second than the first phase. Therefore, it showed a potent activity on both acetic acid-induced abdominal constrictions and tail immersion test

Pyrogen, an induced fever substance includes oxygenous pyrogen and endogenous pyrogen. Analgesic and antipyretic activities are commonly mentioned as characteristics of drugs which have an inhibitory effect on prostaglandin biosynthesis. The yeast induced pyrexia in rat model was, therefore, employed to investigate the antipyretic activity of the extract. The extract was found to exert a significant lowering of body temperature, and its effect was similar to that of aspirin (standard drug). The results seem to support the view that the plant has some influence on prostaglandin biosynthesis because prostaglandin is believed to be the regulator of body temperature. Therefore, these results when taken together lead us to conclude that ethanol extract possesses a significant analgesic and antipyretic activity in several animal models at the dose levels examined [31]

\section{ANTIMITOTIC AND ANTIPROLIFERATIVE ACTIVITY}

The antimitotic and antiproliferative effects are important in vitro assays for the screening of anticancer compounds. In the study conducted by the Saboo et al., mitotic index of the extracts clearly indicates the efficiency of the plant in the inhibition of cancer cell growth by affecting microtubules. The observed antiproliferative effect may be due to the inhibition of cell growth during the cell cycle, as they reduce the rate of cell division by preventing the entry of the cell into the prophase and subsequent phases, which accredited the results of antimitotic and antiproliferative study [32]. In Chhattisgarh state, tribal people utilize the plant for the treatment of breast cancer [9]. Breast cancer is one of the predominant disease-causing huge life loss of women every year globally [33]. Based on that, our earlier study was carried out to provide a scientific support by analyzing the cytotoxic activity of the plant. The chloroform and ethanol extracts of the plant were analyzed and were found a stronger activity with ethanol extract against breast cancer cell line (MCF-7), cervical cancer cell line (He-La) and laryngeal epithelial carcinoma cell line (HEp2).The results obtained are correlated its use in folk medicine in the treatment of cancer [34].

\section{ANTI-DIABETIC ACTIVITY}

In recent trends, herbal products trigger the search of biologically active compounds as the complementary and alternative medicine for diabetes mellitus. Anti-diabetic activity of the plant was examined in both in vitro amylase assay and in vivo streptozotocin (STZ)nicotinamide induced Type 2 diabetic rats by Narendra et al. [35]. It has been identified that methanolic extract of the plant leaves has moderate $\alpha$-amylase inhibitory activity $\left(\mathrm{IC}_{50}=91.3 \mu \mathrm{g} / \mathrm{ml}\right.$ ). Almost all the tested extracts prominently reduces blood glucose levels in STZ-nicotinamide induced diabetic rats. The methanolic extract has shown an estimable decrease of blood glucose level $(p<0.01)$ along with glibenclamide. The results confirmed the anti-diabetic property of the plant extract against Type 2 diabetes mellitus [35].

\section{CONCLUSION}

T. indicum is a weed plant which is now explored as a prominent herb and become an inevitable one in the medicinal field due to its extensive usage. The rural people of India and Pakistan are following the traditional methodology of the plant in curing various diseases which are overviewed in this manuscript. The various pharmaceutical and pharmacological analysis of the plant that is carried out is the substantiation for its importance in the herbal medicinal field. Even then, it is still treated as a scientifically un-investigated plant as further clinical trials and isolation of more phytoconstituents are yet to be carried out. The present review hence reveals the full therapeutic potential of this plant and invites the further researches to provide a platform establish it as a standard drug in the pharmaceutical industry.

\section{CONFLICTS OF INTEREST}

The author has no conflict of interest.

\section{REFERENCES}

1. Hasan M, Ahmad S, Mahmood K. Chemical investigation of Trichodesma indicum leaves-I: Non-steroidal constituents of the petroleum ether extract. J Chem Soc Pak 1982;4:281-3.

2. Banerjee SP, Pramanik BB. A taxonomic revision of indo Burmese Trichodesma boraginaceae. Bull Bot Surv India 1975;17:108-23.

3. Behera SK, Panda A, Behera SK, Misra MK. Medicinal plants used by the kandhas of Kandhamal district of Orissa. Indian J Tradit Know 2006;5:519-28.

4. Periyanayagam JB, Sharma JK. Evaluation of anti diarrhoeal potential of Trichodesma indicum root extract in rats challenge ex vivo methods. Find Exp Clin Pharmacol 2005;27:533-7.

5. Ganesan G, Venkateshan G, Banumathy N. Medcinal plants used by ethnic group of Thottianaickans of semmalai hills (reserve forest). Thiruchirapalli district, Tamil Nadu. Indian J Tradit Know 2006;5:245-52.

6. Ahmad SS. Medicinal wild plants from lahore-islamabad motorway(M-2). Pak J Bot 2007;29:355-75.

7. Sankaranarayanan S, Bama P, Ramachandran PJ, Kalaichelvan PT, Deccaraman M, Vijayalakshimi M, et al. Ethnobotanical study of medicinal plants used by traditional users in Villupuram district of Tamil Nadu, India. J Med Plants Res 2010;4:1089-101.

8. Qureshi SJ, Khan MA. Ethno botanical study of Kahuta from Rawalpindi District, Pakistan. Online J Biol Sci 2001;1:27-30.

9. Qureshi SJ, Khan MA, Ahmad M. A survey of useful medicinal plants 
of Abbattabad in Nortehn Pakistan. Trakia J Sci 2008;6:39-51

10. Tirky A. Ethanomedicinal Investigation on Plants of District Raigarh, Madhya Pradesh, (Ph.D Thesis, Submitted to Barkatullah University, Bhopal M.P India); 2002

11. Abbasi AM, Ajabkhan M, Ahmed M, Zafar M. Herbal medicines used to cure various ailments by the inhibitants of Abbottabad district, North West a frontier province, Pakistan. Indian J Tradit Know 2010;9:175-83.

12. Prusti AB, Beheha KK. Ethno botanical exploration of Malkangiri district of Orissa, India. Ethnobotanical Leaflets 2007;11:148-638.

13. Qureshi R, Bhatti GR. Ethnobotony of plants used by the Thari people of Nara desert, Pakistan. Fitoterapia 2008;79:468-73.

14. Wassel G, El Menshawi B, Saeed A. Toxic pyrrolizidine alkaloids of certain boraginaceous plants. Acta Pharm Sin 1987;24:199-204.

15. Bull LB, Culvenor CC, Dick AT. The Pyrrolizidine Alkaloids. Amsterdam: North-Holland Publishing Co.; 1968. p. 1-93.

16. Mangai SA, Ravi S. Comparative corrosion inhibition effect of imidazole compounds and of Trichodesma indicum (Linn) R. Br. on C38 steel in $1 \mathrm{M} \mathrm{HCl}$ medium. J Chem 2013;1-4.

17. Singh B. Scope of Arid Zone Plants as Medicinal Agents. Jaipur, India: $\mathrm{Ph} . \mathrm{D}$. Thesis, University of Rajasthan; 2001

18. Hassan M, Ahmed S, Mahmood K. Chemical investigation of Trichodesma indicum leaves. I.Non-steroidal constituents of the petroleum ether extracts. J Chem Soc Pak 1982;4:281-3.

19. Hosamani KM. Recinoleic acid, cyclopropene acids in Trichodesma zeylanicum seed oil. Phytochemistry 1994;37:394-6.

20. Peryanayagam JB, Sharma SK, Pillai KK, Pandurangan A, Kesavan D. Evaluation of antimicrobial activity of ethanol extract and compounds isolated from Trichodesma indicum (Linn) $\mathrm{R} \mathrm{Br}$ root. J Ethano Pharmacol 2012;42:283-6.

21. Badami RC, Patil KB. Minor seed oils: Physico chemical characteristics and fatty acid composition of seven minor oils. J Oil Technol Ass India 1975;7:82-4.

22. Periaynayagam JB, Sharma BK, Pillai KK. Anti-inflammatory activity of Trichodesma indicum root extract in experimental animals. J Ethanopharmacol 2006;104:410-4.

23. Srikanth K, Murugesan T, Ch AK, Suba V, Das AK, Sinha S, et al. Effect of Trichodesma indicum extract on cough reflex induced by sulphur dioxide in mice. J Phytomed 2002;9:75-7.
24. Khan T, Ahmad, M, Ahmad, W, Qazi Najam us Saqib and Choudhary M Iqbal. Preliminary evaluation of the antispasmodic and lipoxygenase inhibitory effects of some selected medicinal plants. Pharm Biol 2009; 47:1137-41.

25. Weatherbura MW. Phenol-hypochlorite reaction for determination of ammonia. Anal Chem 1967;39:971-4.

26. Cannell RJ, Kellam SJ, Owsianka AM, Walker JM. Results of a large scale screen of microalgae for the production of protease inhibitors. Planta Med 1988;54:10-4.

27. Ahmad M, Khana T, Nisar M, Lodhi MA, Ahmad W. In vitro inhibition of urease and $\alpha$ - chymotrypsin by some selected indigenous medicinal Plants. Int Chem Pharm Med 2005;2:179-81.

28. Mubarack HM, Doss A, Dhanabalan R, Venkataswamy R. In vitro antimicrobial effects of some selected plants against bovine mastitis pathogen. HYGEIA J Drugs Med 2011;3:71-5.

29. Saboo SS, Tapadiya GG, Khadabadi SS. Antimicrobial potential of tropical plant Trichodesma indicum and Trichodesma sedgwickianum. Res J Microbiol 2013;8:63-9.

30. Khan T, Ahmad M, Khan R, Khan H, Choudhary MI. Phytotoxic and insecticidal activities of medicinal plants of Pakistan, Trichodesma indicum, Aconitum leave and Sauromanta guttatum. J Chem Soc Pak 2008;30:251-5.

31. Periyagam JB, Sharma SK, Pillai KK. Evaluation of analgesic and antipyretic potential of Trichodesma indicum root extracts in animal models. Int J Pharm Sci Lett 2011;1:1-6.

32. Saboo SS, Tapadiya GG, Lamale JJ, Khadabadi SS. Phytochemical screening and antioxidant, antimitotoxic and antiproliferative activities of Trichodesma indicum shoot. Anc Sci Life 2014;34:113-8.

33. Jayadhree V, Priyanak S, Reshma A. A review on screening methods of breast cancer, cancer biomarkers and phyto constituents against breast cancer. Asian J Pharm Clin Res 2017;10:17-21.

34. Mangai SA, Subban R. In vitro cyto toxicity of Trichodesma indium Linn R.Br., extracts against three human cancer cell lines. Asian J Pharm Clin Res 2014;7:103-5.

35. Narendra K, Prasad MS, Joshi DS, Reddi KV, Swathi J, Swajanya KM, et al. Anti-diabetic activity of Trichodesma indicum (L) leaf extracts. J Biol Sci Opin 2015;3:259-65. 